\title{
Exploring the Link between Athletic Identity, Self-compassion, Communication, and Mental Toughness of Table Tennis Student-
}

\section{Athletes}

\author{
Exploración del vínculo entre identidad deportiva, autocompasión, \\ comunicación y fortaleza mental de los estudiantes-atletas de tenis de \\ mesa
}

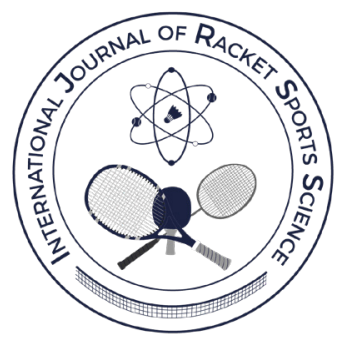

\author{
Maridette Joyce D. Maranan (101, 2; Arnulfo V. Lopez ${ }^{1}$ \\ 1 Department of Psychology, Lyceum of the Philippines University Cavite, General Trias, Cavite, \\ Philippines and University of Santo Tomas, Graduate School \\ 2 Arellano University School of Law, and University of Santo Tomas, Graduate School
}

Received: 15-12-2020

Acepted: 14-04-2021

\begin{abstract}
Table tennis student-athletes should be mentally tough as they train and perform under extreme pressure. It is essential to identify other mental skills that will aid mental toughness development. Accordingly, the study focused on assessing athletic identity, self-compassion, and intra-team communication. The relationship between the constructs was also explored. A multi-part questionnaire was fielded to 230 college student-athletes participating in table tennis singles event. Findings indicate high levels of athletic identity and intra-team communication among the participants; while moderate levels for self-compassion and mental toughness. Structural equation modeling revealed the dynamic relationship between the constructs. On one hand, self-compassionate participants who highly recognize their role as athletes, and communicate with the team are more mentally tough. On the other hand, uncompassionate self-responding lead student-athletes to become mentally weak. The study provides useful insights for practitioners in designing mental skills training geared towards optimal functioning and psychological wellness of young athletes.
\end{abstract}

Keywords: athletic identity; mental toughness; self-compassion; student-athletes; table tennis.

\section{Resumen}

Los estudiantes-atletas de tenis de mesa deben tener fortaleza mental debido a que su entrenamiento y desempeño se dan bajo una presión extrema. Es fundamental identificar otras habilidades mentales que ayuden al desarrollo de la fortaleza mental. En consecuencia, el estudio se centró en la evaluación de la identidad deportiva, la autocompasión y la comunicación dentro del equipo. También se exploró la relación entre los constructos. Se envió un cuestionario de varias partes a 230 estudiantes-atletas universitarios que participaban en pruebas individuales de tenis de mesa. Los resultados indican altos niveles de identidad deportiva y comunicación dentro del equipo entre los participantes, a la vez que evidenció niveles moderados para la autocompasión y la fortaleza mental. Los modelos de ecuaciones estructurales revelaron la relación dinámica entre los constructos. Por un lado, los participantes autocompasivos que reconocen en gran medida su papel como atletas y se comunican con el equipo poseen mayor fortaleza mental. Por otro lado, la falta de autocompasión y el individualismo conllevan a la debilidad mental de los estudiantes-atletas. El estudio proporciona información útil para los profesionales a la hora de diseñar un entrenamiento de las habilidades mentales orientado al funcionamiento óptimo y al bienestar psicológico de los jóvenes atletas.

Palabras clave: identidad deportiva; fortaleza mental; autocompasión; estudiantes-atletas; tenis de mesa.

Correspondence author: Maridette Joyce D. Maranan, maridette.maranan@lpu.edu.ph

Cite this article as:

Maranan, M., Lopez, A. (2020). Exploring the Link between Athletic Identity, Self-compassion, Communication, and Mental Toughness of Table Tennis Student-Athletes. International Journal of Racket Sports Science, 3(1), 1-9.

This is an open access article under the CC BY license (https://creativecommons.org/licenses/by/4.0/). 


\section{INTRODUCTION}

Table tennis athletes perform under extreme pressure (Ahsan \& Mohammad, 2017). They are expected to render the play with high-intensity efforts, recover quickly between matches and rallies; and maintain cognitive function. The execution of goaldirected movements and specific motor skills, within a limited time frame, requires good planning and coordination (Faber, Nijhuis-Van Der Sanden, ElferinkGemser, \& Oosterveld, 2015; Mansec, Pageaux, Nordez, Dorel, \& Jubeau, 2018; Zagatto, Papoti, dos Reis, Beck, \& Gobatto, 2014). Thus, the athletes should not only be conditioned physically but mentally as well (Kondric, Zagatto, Sekulic, 2013) - someone who embodies psychological qualities such as mental toughness (Chu, Chen, I. Chen, L. Huang, \& Hung, 2011). Mentally tough athletes are capable of efficiently performing again after a stressful experience. They face challenges headon with confidence, persistence, and control (Sheard, Golby, \& van Wersch, 2009). Adversely, young athletes who play an individual sport have been reported to exhibit low self-confidence (Yilmaz, Top, Çelenk, Akil, \& Kara, 2015). They are also prone to internalize various types of feedback like losing a match or pressure to perform (Nixdorf, Frank, Hautzinger, \& Beckmann, 2013). This highlights the need to identify other mental skills that will help develop mental toughness among table tennis student-athletes.

According to Vealey (2012), there are four types of mental skills needed to attain athletic success and address personal well-being - performance, personal development, foundation, and team skills. Performance skills, such as mental toughness, are crucial to skill execution. Personal development skills, like a clear self-concept, embody maturation indicators. Foundation skills, such as productive thinking, are fundamental sources found within the self. Team skills, such as team unity, produce an effective environment that facilitates the achievement of group objectives. The dynamics of these skills are also mirrored in athletic identity, self-compassion, and intra-team communication, respectively. Interestingly, studies have shown that some aspects of these skills may influence mental toughness.

Brewer and colleagues defined athletic identity as the "degree to which an individual identifies with the athletic role" (Gapin \& Petruzzello, 2011, p. 1002). It has been noted that athletes with strong athletic identity set specific athletic goals. Goal setting gave them the reason to continue with their training and helped them identify themselves as athletes (Poucher \& Tamminen, 2017). This characteristic is also salient for mentally tough individuals who exhibit goal-directed behaviors (Gucciardi, 2017). In the qualitative study of Connaughton, Hanton and Jones (2010), capacity beliefs and focus are intensified when athletes recognize their sense of accomplishment in sports participation. This indicates that the pleasant feelings associated with the athletic role can influence mental toughness.
Aside from athletic identity, mindfulness has been found to increase confidence to surpass challenges and general levels of mental toughness (Ajilchi et al., 2019; Sheard, 2012). It improved their attention, helped understand their feelings, reduced perceived stress, increased commitment in training routines, and facilitated behavioral and emotional regulation. Mindfulness is a characteristic of a self-compassionate individual coupled with kindness towards the self and recognition that they are not alone as they face adversities (Krieger, Berger, \& Holtforth, 2017).

In a mental toughness training program, good communication skill has been identified as one of the areas that should be developed among athletes (Pattison, 2011). It can bring about unity (Sheryl \& Bruce, 2005, as cited in Muthiaine, 2014), which in turn, can promote mental toughness among team members (Fourie \& Potgieter, 2001, as cited in Young \& Pearce, 2011).

The Basic Psychological Needs Theory (BPNT) also provides further support on the influence of athletic identity, self-compassion, and intra-team communication on mental toughness. This theory states that an individual's psychological growth and development largely depend on the satisfaction of three needs - autonomy, competence, and relatedness (Deci \& Ryan, 2015). People whose needs are satisfied are more likely to work towards the attainment of their goals with consistent effort compared to those whose needs are restrained. The kind of perseverance described herein is a "behavioral signature" of mental toughness (Gucciardi, Peeling, Duckera, \& Dawson, 2016 p. 81). Thus, it can be inferred that student-athletes whose needs are satisfied are tougher mentally. Accordingly, athletic identity, self-compassion, and intra-team communication may satisfy the three basic needs. Ryan and Deci (2012) indicated that the main function of identity adoption (i.e athletic identity in the sports context) is to help fulfill basic psychological needs. Similarly, the concept of relatedness in BPNT also shares similarities with the common humanity dimension of self-compassion. Common humanity serves as an aid for athletes to perceive others who have similar experiences and facilitate acceptance of social support. It serves as a vital strategy to cope with setbacks such as poor performance, injury, or an unwanted outcome in a competition (Mosewich, Crocker, \& Kowalski, 2014). Adopting effective intrateam communication strategies also fosters needs satisfaction. These consist of exchanging messages that orient, stimulate, and evaluate the performance of each member (Onag \& Tepeci, 2014), which is akin to having an autonomy-supportive environment that is needed to satisfy the needs. By and large, BPNT posits that the satisfaction of the three basic psychological needs cultivates a more internalized behavior and self-determined motivation (Barbeau et al., 2009, as cited in Reifsteck, Gill, \& Labban, 2016). The present study argued that this internalized behavior and 
self-determined motivation can be translated into mental toughness.

While traces can be found in the extant literature on how athletic identity, self-compassion, and intra-team communication may influence mental toughness, no research has been made to directly test their relationship. Also, there is scarcity in literature regarding the assessment of mental skills of table tennis student-athletes. To address these gaps, this study was pursued to (1) identify table-tennis studentathletes' level of athletic identity, self-compassion, intra-team communication, and mental toughness, and (2) test the relationship between the constructs. From the theoretical expectation and conceptual standpoint, the hypothesis, there is a significant relationship between the constructs, was tested (Figure 1).

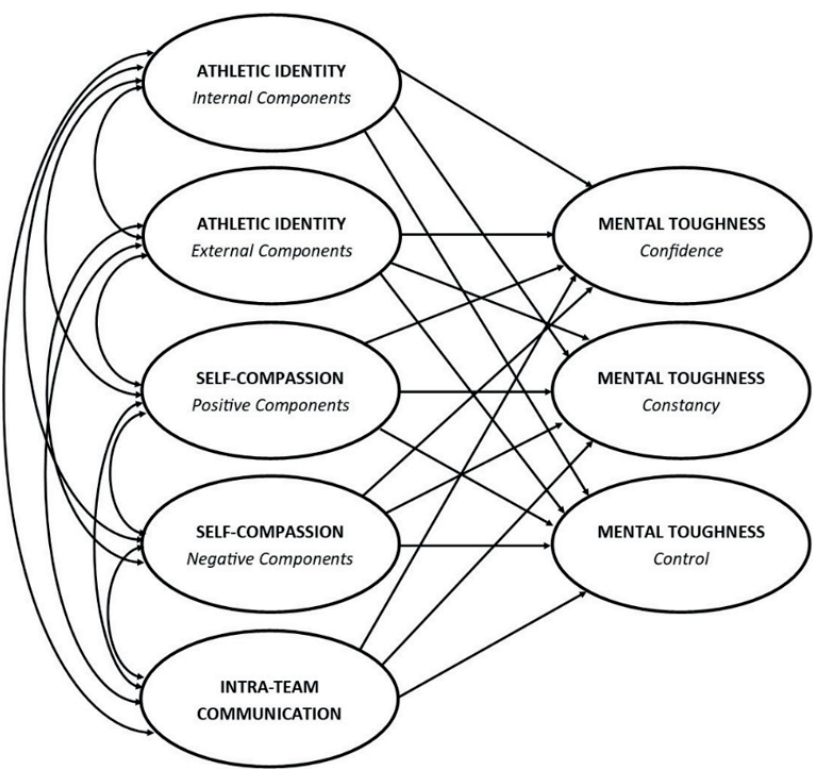

Figure 1. Hypothesized model showing the relationship between the constructs.

\section{MATERIALS AND METHODS}

\section{Participants}

Participants were 230 college student-athletes (Mage $=20$ years; $\mathrm{SD}=1$ ) playing in table tennis singles event. Total population sampling was used as there is a limited number of student-athletes playing the said sport. They were selected from the 25 member schools of different athletic associations in the Philippines. More than half of the participants are male $(57 \%$, $\mathrm{n}=131)$. While most of them are in their first two years in tertiary education (1st year: $44 \%, n=102$; and 2 nd year: $36 \%, n=83)$, the majority started as junior studentathletes $(89.6 \%, n=206)$. They have been playing table tennis for an average of 8 years $(S D=3)$.

\section{Design and Procedures}

Descriptive and correlational designs were utilized in this study. Before collecting the data, approval was sought from the Institutional Ethics Review Committee of the [name of the institution; removed for anonymity]. Participants voluntarily signed an informed consent form that includes pertinent information about the study as well as their rights. The following modified questionnaires were utilized to measure the constructs (original developers granted permission to use and modify the instrument to include translation of statements to the local language; pilot testing was also conducted):

Athletic Identity Measurement Scale-Plus (AIMSPlus). This scale was originally developed by Cieslak (2004). It consists of 20 items and demonstrates good internal consistency $(\alpha=.87)$. Confirmatory factor analysis revealed acceptable indices $(\mathrm{CMIN} / \mathrm{df}=2.146$, RMSEA $=0.071, C F I=.902, I F I=.904)$ that support the original components of athletic identity - internal and external. The internal components include Positive Affectivity [good feelings in sport participation], Selfidentity [awarenes of the athletic role], and Negative Affectivity [negative reactions towards undesirable athletic outcomes]. The external components are Exclusivity [self-worth is gauged through sports participation] and Social Identity [awareness that others see him as an athlete]. Participants rated the items on a 7-point scale ranging from 1 (strongly disagree) to 7 (strongly agree).

Self-compassion Scale (SCS). Participants rated the 24 items on a 5-point scale where endpoints range from 1 (almost never) to 5 (almost always). Confirmatory factor analysis revealed indices that shows adequate fit for the two-factor self-compassion model of Neff (2003) - positive $(\mathrm{CMIN} / \mathrm{df}=1.458, \mathrm{RMSEA}=0.045, \mathrm{CFI}=.969, \mathrm{IFI}$ $=.970)$ and negative $(C M I N / d f=1.876$, RMSEA $=0.062$, $\mathrm{CFI}=.945, \mathrm{IFI}=.946)$. Positive self-compassion includes Self-Kindness [being kind and understanding to oneself], Common Humanity [acknowledgment that he is part of a larger community], and Mindfulness [neutrally embracing painful feelings/thoughts]. Negative self-compassion comprises of Self-Judgment [making harsh/critical judgment about the self], Isolation [sees self as separate from people], and Overidentification [excessively ruminating over negative emotions/cognitions]. The scale demonstrates good internal consistency $(\alpha=.87)$.

Scale of Effective Communication in Team Sports (SECTS-2). This scale was developed by Sullivan and Short (2011) and was used in this study to assess the three communication strategies used by the participants, namely: Acceptance [considers welfare and appreciates everyone], Distinctiveness [use of verbal and non-verbal communication tools that makes the group unique] and Positive Conflict [openly and calmly share thoughts, feelings, and disparities]. The three-factor model was subjected to confirmatory factor analysis and revealed acceptable fit indices $(\mathrm{CMIN} / \mathrm{df}=1.580, \mathrm{RMSEA}=0.050, \mathrm{CFI}=.981, \mathrm{IFI}=.982) . \mathrm{It}$ also demonstrates good internal consistency $(\alpha=.86)$. A total of 11 items were rated by the participants on a 
7-point scale ranging from 1 (hardly ever) to 7 (almost always).

\section{Sports Mental Toughness Questionnaire (SMTQ).} This scale was developed by Sheard et al. (2009) and was used to measure the three components of mental toughness, namely: Confidence [capacity belief to attain goals and outperform opponents], Constancy [determination to commit to tasks], and Control [ability to manage emotions/behavior]. The results of confirmatory factor analysis showed indices of a good model fit $(\mathrm{CMIN} / \mathrm{df}=1.252$, RMSEA $=0.033, \mathrm{CFI}=.982, \mathrm{IFI}$ $=.983$ ), and Cronbach alpha revealed an acceptable reliability index $(\alpha=.78)$. Participants rated 14 items on a 4-point scale, ranging from 1 (not at all true) to 4 (very true).

\section{Analysis}

Means and standard deviations were generated in SPSS 22.0 to determine the levels of athletic identity, self-compassion, intra-team communication, and mental toughness. Higher scores in the scales indicate higher levels in the measured construct. Structural Equation Modeling, through AMOS 24.0, was used to determine the relationship among the variables. Four common measures were utilized to assess the model's goodness of fit: chi-square/degrees of freedom (CMIN/ df), comparative fit index (CFI), incremental fit index (IFI), and root mean square error of approximation (RMSEA). Carmines and Mclver's (1981) ratio rule together with Browne and Cudeck's (1993) criteria served as indicators of adequate fit: CMIN/df in the range of 2 to $1, \mathrm{CFI}$ and $\mathrm{IFI} \geq .90$, and RMSEA Score $\leq$ .08. The magnitude of the regression coefficients was interpreted using the guidelines offered by Kline (2005): small effect for .10 values or less, a medium effect for values around .30, and .50 or above for a large effect.

\section{RESULTS}

\section{Descriptive Results}

Table tennis student-athletes in the study have high levels of athletic identity $(M=57, S D=7)$. Both internal $(M=73, S D=9)$ and external $(M=40, S D=7)$ components received a high rating. Among the sub-components of athletic identity, positive affectivity received the highest mean rating $(M=73, S D=9)$. Participants consider that their sport participation brings a positive impact on their lives and it makes them happy. Conversely, they exhibit moderate levels of social identity $(M=18$, $\mathrm{SD}=5$ ). They strongly disagree that they participate in sport for recognition or fame.

The participants' self-compassion is found to be at moderate levels $(M=3.33, S D=0.421)$. While they highly manifest positive self-compassion behaviors $(M=3.94, \mathrm{SD}=.574)$, they also show moderate levels of uncompassionate self-responding $(M=3.35, \mathrm{SD}=.861)$. They still feel inadequate when faced with failures and takes them too seriously even if they can regulate their emotions well.

As for intra-team communication, they always use effective strategies $(M=5.71, \mathrm{SD}=.896)$. Acceptance $(M=5.93, \mathrm{SD}=.975)$ received the highest mean rating. They usually ensure that all team members are included when they communicate. They also trust each other.

Results also revealed that the table tennis studentathletes exhibit moderate levels of mental toughness $(M=40, S D=6)$. They have high levels of confidence $(M=19$, $\mathrm{SD}=3)$ and constancy $(M=7, \mathrm{SD}=1)$ but their control is at moderate levels $(M=15, S D=4)$. They do recognize their unique qualities as athletes. Nonetheless, they get anxious, angry, and frustrated when things do not go their way.

\section{Structural Equation Modeling Results}

The relationships between athletic identity, selfcompassion, intra-team communication, and mental toughness were analyzed through the use of Structural Equation Modeling (SEM). Figure 2 shows the emerging model. It generated indices that demonstrate an adequate $(\mathrm{CMIN} / \mathrm{df}=1.785$, RMSEA $=0.059)$ and a very good fit $(\mathrm{CFI}=.902, \mathrm{IFI}=.904)$.

In the model, the positive correlation between athletic identity, positive self-compassion, and intrateam communication can be noted. The interplay between these variables influences the mental toughness components in a positive light. The more student-athletes exhibit high levels of said skills, the more they become mentally tough. Standardized regression weights of $.233, .405$, and .256 were calculated for the direct impact of external athletic identity, positive self-compassion, and intra-team communication to the constancy component of mental toughness. The $48.2 \%$ variance in the table tennis student-athletes' constancy can be explained by these mental skills. A direct association can also be noted between external athletic identity (.265), positive selfcompassion (.464), and the confidence component of mental toughness. Nevertheless, an inverse relationship was revealed between negative selfcompassion and confidence (-.217). Uncompassionate behaviors are accounted for the $42.4 \%$ variance of the student-athletes' confidence. It can also be noted from the figure that uncompassionate self-responding $(-.737)$, while not related to other constructs, negatively influences the control component of mental toughness and can be accounted for its $54.3 \%$ variance.

The figure also shows that the internal component of athletic identity is not directly associated to any of the components of mental toughness but it is related to external athletic identity (.845), positive selfcompassion (.490), and intra-team communication (.403). This indicates the indirect relationship between internal athletic identity and mental toughness. 


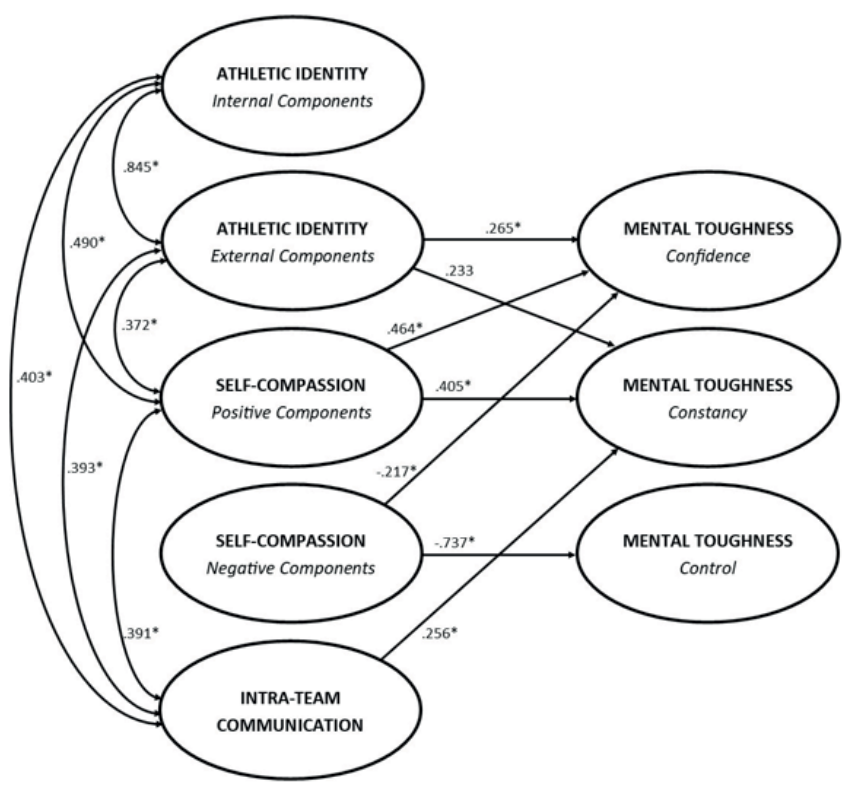

Figure 2. Results of structural equation modeling showing standardized estimates of the proposed model with regression coefficients significant at $p<0.05,{ }^{*} p<0.01$.

Generally, the model revealed the medium to a large direct and indirect effect of the components of athletic identity, self-compassion, and intrateam communication on mental toughness. Among these mental skills, negative self-compassion can be considered as the most influential construct that affects mental toughness followed by positive selfcompassion. These results show the acceptance of the hypothesis raised in the study.

\section{DISCUSSION}

The objectives of the present study were twofold. The first objective was to assess the levels of athletic identity, self-compassion, intra-team communication, and mental toughness among the participants. It was found out that table tennis student-athletes have high levels of athletic identity and intra-team communication, while moderate levels for selfcompassion and mental toughness.

The high levels of athletic identity among the participants may be attributed to the fact that they are involved in sports at an early age. Some of them started playing table tennis since they were kids and most of them are student-athletes since high school. In the sports context, identity as an athlete starts to form during high school. At this stage, studentathletes recognize the need for time and psychological commitment to become successful in the field. When they reach college, their identities become crystallized as they strongly identify with their athletic role (Johnson \& Migliaccio, 2009, as cited in Heird \& Steinfeldt, 2013). Their early sports involvement could also explain their frequent use of effective communication strategies. They are trained on how to properly connect with others. Sports is a highly interactive activity where athletes can interact with various individuals, these include but are not limited to their teammates, coaches, and the audience. It is a great avenue for young individuals to learn good communication skills. Some studies have demonstrated the ability of sports to develop communication efficacy (Ishak, 2017).

The moderate levels of mental toughness may be due to their inability to control emotions and direct behavior at times of difficulties. While they are confident about their abilities and are committed to their goals, they still worry about their performance. This anxiety leads to their inability to focus well during sports performance (Chen, I. Chang, Hung, Chen, L. \& Hung et al., 2010). They become preoccupied with poor skill execution instead of finding ways on how to improve their tactics. This is consonant with the study of Martinent and Ferrand (2009) where they found the facilitating and debilitating roles of emotions among table tennis athletes. Anxiety and other emotions (e.g. anger and hope) brought about positive influences, but these also reduced their concentration, motivation, and confidence. These emotions also brought forth maladaptive behaviors, like committing errors and illtimed forceful strokes. Similarly, table tennis athletes who are inclined to either express anger outwardly or suppress angry feelings are considered to exhibit poor psychological adjustment (González-García \& Martinent, 2020). These findings demonstrate that emotions, if not managed well, can affect the mental state and performance of athletes. The difficulty of the participants to control their emotions is confirmed by their moderate levels of self-compassion. They sometimes overidentify, isolate, and judge themselves when faced with adversity. These confirm the need to develop the mental skills of table tennis studentathletes, particularly self-compassion and mental toughness.

In light of the aforementioned findings, it is important to identify constructs that are related to them. This is the focus of the second objective of the study. Findings revealed that student-athletes who prioritize their sport and cognizant of their social roles are more responsible, committed, and confident. This can be attributed to the sense of obligation that athletes may feel as they continue to participate in sport (Scanlan, T., Chow, Sousa, Scanlan, L., \& Knifsend, 2016). It is imperative for them to continuously and consistently plan and perform tasks that would make them better. This is because sport defines their dayto-day lives and people see them as athletes. The external forces that complete their athletic identity shape their sporting attitude. They try to seek the ideals attached to being an athlete - making sure that they attend to the social roles and expectations. As they do this, the more people will recognize them, and the more that they would feel that they belong to a community that supports them as athletes. One of these communities is their team. As they feel accepted in this group, they will not hesitate to communicate with them. This creates a positive team atmosphere. 
Athletes are more likely to evaluate stressors as challenging experiences if they feel free to express their feelings, can receive guidance, and fulfill demands with support from others. (Ntoumanis, Edmunds, \& Duda, 2009). They will engage more in volitional behaviors to improve and accomplish their goals as they feel the support of the team. This support can lead to their commitment to perform well. They will spend more time in sporting activities, which in turn may strengthen capacity beliefs. Beaumont, Maynard and Butt (2015) noted that one way to develop and maintain confidence in sport is through the awareness of the athlete's unique strength and how to utilize it to his advantage. This awareness will only materialize if student-athletes will work together with the team during training and competition. Continuous team interaction also enables the formation of identities and prompts the differentiation of self from others (Anderson \& Coleman, 2008, as cited in Da Silva et al., 2016). Thus, student-athletes who engage more with the team will have more opportunities to identify their unique abilities that will later define their confidence. These lend credence to the notion that the sporting abilities of the athletes are reinforced by society as they perform their obligations (Beamon, 2012).

Nevertheless, external athletic identity and intrateam communication are not the only constructs that can influence mental toughness. Findings show that those who exhibit higher levels of positive selfcompassion have higher levels of confidence and constancy as well. Karanika and Hogg (2016) indicated that self-compassionate individuals are not defensive and strive to take a clear picture of their strengths and weakness. As indicated earlier, the acknowledgment of one's capacities is the first step in boosting one's confidence. Likewise, athletes who are capable of accepting their weaknesses with kind understanding and balanced awareness are more likely to become committed to their goals. This is because they can nurture and make themselves better in a safe and non-judgmental environment (Breines \& Chen, 2012). Consequently, those who judge themselves harshly cast doubts on their inherent abilities. They will not be able to fully recognize their competence as their minds are clouded with their flaws and inadequacies. Uncompassionate self-responding does not only influence confidence in a negative light. It also affects the athlete's control. The more studentathletes become self-critical, feels isolated, and are preoccupied with their negative thoughts and feelings, the more that they lose their control. They are consumed by their pessimistic attitude towards themselves and are wrapped up by emotions that are harmful to sports performance. They are unable to focus on their tactics and techniques. These findings are clear indications that self-compassion provides young individuals a "secure, positive sense of self" (Barry, Loflin, \& Doucette, 2015) and its opposite will lead to a thwarted perception of their potentials making them mentally weak.
Interestingly, negative self-compassion is not directly related to athletic identity, positive selfcompassion, and intra-team communication. This finding provides mixed support for the study of Neff et al. (2018). On one hand, the present study shows that the two components of self-compassion are not interrelated - they are considered as two separate units; this is in contrast to the contention of Neff et al. (2018). On the other hand, this study does acknowledge the varying influence of both components on specific outcomes. The emerging model revealed that positive self-compassion is correlated to athletic identity and intra-team communication and has a medium impact on confidence and constancy. On the contrary, negative self-compassion has a large effect on the control component of mental toughness and is not related to athletic identity and intra-team communication. Taking these into consideration, each component of selfcompassion should be given focus when developing the mental skills of table tennis student-athletes. Positive self-compassion should be maintained at high levels while reducing negative self-compassion.

Considering the importance of compassionate selfresponding, it is noteworthy to examine its positive relationship with intra-team communication. The more student-athletes engage in effective communication, the more that they nurture a positive atmosphere where they can openly discuss performance issues/ concerns. This will then prompt them to become kind to themselves as they are aware that there are people who are ready to accept them whatever their performance outcomes are. They will feel that they are not alone in their endeavors. The sense of belonging that they experience from the team makes them feel more connected to others. This positive experience can prompt student-athletes to accept, respect, and trust their team as well.

It is also important to point out the indirect influence of internal athletic identity on mental toughness. It further substantiates the notion of satisfying all the basic needs including relatedness to make student-athletes mentally tough. The internal component of athletic identity, taken alone, deals with self-evaluation and interpretation of the athlete without the influence of society. Thus, internal athletic identity cannot directly affect mental toughness as the presence of others is considered essential in making an athlete mentally tough. As Galli and Vealey (2008, as cited in Mahoney, Ntoumanis, Mallett, \& Gucciardi, 2014) noted, athletes are motivated to recalibrate their performance level, functioning, and development in the presence of social support. They can adapt well amidst difficulties if they feel the connection to a wider social fabric - a dimension tapped by external athletic identity, positive self-compassion, and intrateam communication. Aside from this, it should also be noted that some internal components of athletic identity have a contradictory influence on the anxiety of table tennis athletes. A clear self-concept decreases 
anxiety, which may help them cope with challenges, but high levels of negative affectivity can elevate it (Masten, Tušak, \& Faganel, 2006). Thus, having high levels of internal athletic identity may not directly influence the ability of the athletes to face challenges head-on. Nevertheless, it is worth noting that internal athletic identity was taken here as a collective construct. Breaking down its components may provide alternative results on its influence on mental toughness.

While the study offers insights on which mental skills are to be developed among these young table tennis athletes, some limitations should be noted. One of which is the self-report measures that were utilized and may have resulted in biased ratings of the constructs. Also, due to the sampling used in the study, few of the participants recently joined the team and have limited experience as student-athletes. Future research may consider using additional measures to confirm the results and consider playing years in the inclusion criteria. Comparison of the mental skills according to a variety of profiles (e.g. age, number of years as student-athletes, etc.) may also yield interesting results that could aid in developing suitable training programs for these athletes. Extending the study to include other individual and team sports may also provide a more conclusive finding on the link between athletic identity, self-compassion, intra-team communication, and mental toughness.

\section{CONCLUSION}

The findings provide evidence that the mental skills capable of satisfying psychological needs can make table tennis student-athletes mentally tough. The dynamic link that exists among the skills calls sports practitioners to be judicious in developing mental toughness. In light of the findings, it is recommended to improve the levels of mental toughness by tapping on athletic identity, intra-team communication, and self-compassionate behaviors. Among these, the focus should be given to self-compassion. It should be noted that training student-athletes to engage more in selfcompassionate behaviors will not lead to addressing uncompassionate self-responding. Thus, the latter should be treated as a separate construct needing more attention as it can greatly influence mental toughness negatively. Table tennis student-athletes should not only learn how to be self-compassionate but should also know how to hold back or at least lessen the uncompassionate behavior towards the self.

\section{REFERENCES}

Ahsan, M., \& Mohammad, A. (2017). Mental toughness as a determinant factor of performance in table tennis. European Journal of Physical Education and Sport Science, 3(12), 194-203. https://doi. org/10.5281/zenodo.1092745
Ajilchi, B., Amini, H. R., Reza, H., Ardakani, Z. P., Zadeh, M. M., \& Kisely, S. (2019). Applying mindfulness training to enhance the mental toughness and emotional intelligence of amateur basketball players. Australasian Psychiatry, 27(3), 291-296. https://doi. org/10.1177/1039856219828119

Barry, C., Loflin, D., \& Doucette, H. (2015). Adolescent self-compassion: Associations with narcissism, selfesteem, aggression, and internalizing symptoms in at-risk males. Personality and Individual Differences, 77, 118-123. http://dx.doi.org/10.1016/j. paid.2014.12.036

Beamon, K. (2012). "I'm a baller": Athletic identity foreclosure among African-American former student-athletes. Journal of African American Studies, 6(1), 195-208. https://doi.org/10.1007/ s12111-012-9211-8

Beaumont, C., Maynard, I. W., \& Butt, J. (2015). Effective ways to develop and maintain robust sport-confidence: Strategies advocated by sport psychology consultants. Journal of Applied Sport Psychology, 27(3), 301-318. https://doi.org/10.1080/ 10413200.2014.996302

Breines, J. G., \& Chen, S. (2012). Self-compassion increases self-improvement motivation. Personality and Social Psychology Bulletin, 38(9), 1133-1143. https://doi.org/10.1177/0146167212445599

Browne, M.W., \& Cudeck, R. (1993). Alternative ways of assessing model fit. In K. A. Bollen \& J. S. Long (Eds.), Testing structural equation models (pp. 136-162). Sage.

Carmines, E. G., \& Mclver, J.P. (1981). Analyzing models with unobserved variables. In G. W. Bohrnstedt \& E. F. Borgatta (Eds.), Social measurement: Current issues (pp. 65-115). Sage.

Chen, I. T., Chang, C. W., Hung, C. L., Chen, L. C., \& Hung, T. M. (2010). Investigation of underlying psychological factors in elite table tennis players. International Journal of Table Tennis Sciences, 6, 48-50.

Chu, C. Y., Chen, I. T., Chen, L. C., Huang, C. J., \& Hung, T. M. (2011, May 5-7). Sources of psychological states related to peak performance in elite table tennis player. International Journal of Table Tennis Sciences, 7, 84-88.

Cieslak, T. J., II. (2004). Describing and measuring the athletic identity construct: Scale development and validation [Doctoral Dissertation, Ohio State University]. Retrieved from https://www.ohiolink. edu/

Connaughton, D., Hanton, S., \& Jones, G. (2010). The development and maintenance of mental toughness in the World's Best Performers. The Sport Psychologist, 24(2), 168-193. https:/ /doi.org/10.1123/ tsp.24.2.168 
Da Silva, W. R., Ferrari, E. P., Medeiros, T. E., de Freitas, K. T., Tkac, C. M., \& Cardoso, F. L. (2016). "Athletic Identity Measurement Scale": Translation, adaptation, and validation for Brazil. Motriz, Rio Claro, 22(1), 42-47. http://dx.doi.org/10.1590/S198065742016000100006

Deci, E. L., \& Ryan, R. M. (2015). Self-determination theory. In J. D. Wright (Ed.), International Encyclopedia of the Social \& Behavioral Sciences Volume ( $2^{\text {nd }}$ ed., vol. 21, pp. 486-491). Elsevier.

Faber, I. R., Nijhuis-Van Der Sanden, M. W., ElferinkGemser, M. T., \& Oosterveld, F. G. (2015). The Dutch motor skills assessment as tool for talent development in table tennis: A reproducibility and validity study. Journal of Sports Sciences, 33(11), 1149-1158. https://doi.org/10.1080/02640414.2014.9 86503

Gapin, J., \& Petruzzello, S. J. (2011). Athletic identity and disordered eating in obligatory and non-obligatory runners. Journal of Sports Sciences, 29(10), 10011010. https://doi.org/10.1080/02640414.2011.571275

González-García, H., \& Martinent, G. (2020). Perceived anger profiles in table tennis players: Relationship with burnout and coping. Psychology of Sport and Exercise, 50, 101743. https://doi.org/10.1016/j. psychsport.2020.101743

Gucciardi, D. (2017). Mental toughness: Progress and prospects. Current Opinion in Psychology, 16, 17-23. https://doi.org/10.1016/j.copsyc.2017.03.010

Gucciardi, D., Peeling, P., Duckera, K.J., \& Dawson, B. (2016). When the going gets tough: Mental toughness and its relationship with behavioural perseverance. Journal of Science and Medicine in Sport, 19(1), 8186. https://doi.org/10.1016/j.jsams.2014.12.005

Heird, B. E., \& Steinfeldt, J. A. (2013). An interpersonal psychotherapy approach to counseling studentathletes: Clinical implications of athletic Identity. Journal of College Counseling, 16(2), 143-157. https:/ / doi.org/10.1002/j.2161-1882.2013.00033.x

Ishak, A. W. (2017). Communication in sports teams: A review. Communication Research Trend, 36(4), 1-38.

Karanika, K. \& Hogg, M. (2016). Being kind to ourselves: Self-compassion, coping, and consumption. Journal of Business Research, 69(2), 760-76. https://doi. org/10.1016/j.jbusres.2015.07.042

Kline, R. B. (2005). Principles and practice of structural equation modeling ( $2^{\text {nd }}$ ed.). The Guilford Press.

Kondric, M., Zagatto, A. M., \& Sekulic, D. (2013). The physiological demands of table tennis: A review. Journal of Sports Science and Medicine, 12(3), 362370.

Krieger, T., Berger, T., \& Holtforth, M. (2017). The relationship of self-compassion and depression: cross-lagged panel analyses in depressed patients after outpatient therapy. Journal of Affective Disorders, 202, 39-45. https://doi.org/10.1016/j. jad.2016.05.032

Mahoney, J., Ntoumanis, N., Mallett, C., \& Gucciardi, D. (2014). The motivational antecedents of the development of mental toughness: A selfdetermination theory perspective. International Review of Sport and Exercise Psychology, 7(1), 184197. https:/ /doi.org/10.1080/1750984X.2014.925951

Mansec, Y. L., Pageaux, B., Nordez, A., Dorel, S., \& Jubeau, M. (2018) Mental fatigue alters the speed and the accuracy of the ball in table tennis. Journal of Sports Sciences, 36(23), 2751-2759. https:/ /doi.org /10.1080/02640414.2017.1418647

Martinent, G., \& Ferrand, C. (2009). A naturalistic study of the directional interpretation process of discrete emotions during high-stakes table tennis matches. Journal of Sport and Exercise Psychology, 31, 318336. https://doi.org/10.1123/jsep.31.3.318

Masten, R., Tušak, M., \& Faganel, M. (2006). Impact of identity on anxiety in athletes. Kinesiology, 38(2), 126-134.

Mosewich, A., Crocker, P., \& Kowalski, K. (2014). Managing injury and other setbacks in sport: Experiences of (and resources for) high-performance women athletes. Qualitative Research in Sport, Exercise and Health, 6(2), 182-204. https://doi.org/10.1080/21596 76X.2013.766810

Muthiaine, M. C. (2014). Relationship between team cohesion and sports performance among basketball teams in the 2010 National League in Kenya (Master's thesis, Kenyatta University). Retrieved from https: / / ir-library.ku.ac.ke

Neff, K. D. (2003). Self-Compassion: An alternative conceptualization of a healthy attitude toward oneself. Self and Identity, 2(2), 85-101. https://doi. org/10.1080/15298860309032

Neff, K. D., Long, P., Knox, M. C., Davidson, O., Kuchar, A., Costigan, A., Williamson, Z., Rohleder, N., TóthKirály, I., \& Breines, J. G. (2018). The forest and the trees: Examining the association of self-compassion and its positive and negative components with psychological functioning. Self and Identity, 17(6), 627-645. https://doi.org/10.1080/15298868.2018.143 6587

Nixdorf, I., Frank, R., Hautzinger, M., \& Beckmann, J. (2013). Prevalence of depressive symptoms and correlating variables among German elite athletes. Journal of Clinical Sport Psychology, 7(1), 313-326. https://doi.org/10.1123/jcsp.7.4.313

Ntoumanis, N., Edmunds, J., \& Duda, J. L. (2009). Understanding the coping process from a selfdetermination theory perspective. British Journal of Health Psychology, 14(2), 249-260. https://doi. org/10.1348/135910708X349352 
Onag, Z., \& Tepeci, M. (2014). Team effectiveness in sport teams: The effects of team cohesion, intra-team communication and team norms on team member satisfaction and intent to remain. Procedia-Social and Behavioral Sciences, 150, 420-428. https://doi. org/10.1016/j.sbspro.2014.09.042

Pattison, S. (2011). The development and implementation of a mental toughness training programme for young cricketers (Master's Thesis, Rhodes University). Retrieved from https://core. ac.uk/download/pdf/145054795.pdf

Poucher, Z., \& Tamminen, K. (2017). Maintaining and managing athletic identity among elite athletes. Journal of Sport Psychology, 26(4), 63-67.

Reifsteck, E. J., Gill, D. L., \& Labban, J. D. (2016). "Athletes" and "Exercisers": Understanding identity, motivation, and physical activity participation in former college athletes. Sport, Exercise, and Performance Psychology, 5(1), 25-38. https://doi. org/10.1037/spy0000046

Ryan, R. M., \& Deci, E. L. (2012). Multiple identities within a single self: A self-determination theory perspective on internalization within contexts and cultures. In M. R. Leary \& J. P. Tangey (Eds.), Handbook of self and identity ( ${ }^{\text {nd }}$ ed., pp. 225-246). Gulliford Press.

Scanlan, T. K., Chow, G. M., Sousa, C., Scanlan, L. A., \& Knifsend, C. A. (2016). The development of the sport commitment questionnaire-2 (English version). Psychology of Sport \& Exercise, 22, 233-246. https:/ / doi.org/10.1016/j.psychsport.2015.08.002
Sheard, M. (2012). Mental toughness: The mindset behind sporting achievement. Routledge.

Sheard, M., Golby, J., \& van Wersch, A. (2009). Progress toward construct validation of the Sports Mental Toughness Questionnaire (SMTQ). European Journal of Psychological Assessment, 25, 186-193.

Sullivan, P., \& Short, S. (2011). Further operationalization of intra-team communication in sports: An updated version of the Scale of Effective Communication in Team Sports (SECTS-2). Journal of Applied Social Psychology, 41(2), 471-487. https://doi.org/10.1111/ j.1559-1816.2010.00722.x

Vealey, R. (2012). Mental skills training in sport. In G. Tenenbaum \& R. Eklund (Eds.), Handbook of Sport Psychology ( $3^{\text {rd }}$ ed., pp. 287-309). John Wiley \& Sons.

Yilmaz, T., Top, E., Çelenk, Ç., Akil, M., \& Kara, E. (2015). Evaluating the self-confidence levels of teams and individual athletes at the age of 14-16 according to several variables. Ethno Med, 9(2), 203-207. https:/ / doi.org/10.1080/09735070.2015.11905436

Young, J. A., \& Pearce, A. J. (2011). Understanding, developing and maintaining mental toughness in tennis. Medicine and Science in Tennis, 16(2), 18-22. http:/ / hdl.handle.net/10536/DRO/DU:30045198

Zagatto, A. M., Papoti, M., dos Reis, I. G. M., Beck, W. R., \& Gobatto, C. A. (2014). Analysis of cardiopulmonary and metabolic variables measured during laboratory and sport-specific incremental tests for table tennis performance prediction. Science and Sports, 29(2), 62-70. https://doi.org/10.1016/j. scispo.2013.08.001 